\title{
The Pfahlgraben and Saalburg in Germany
}

\section{James Hilton F.S.A.}

To cite this article: James Hilton F.S.A. (1904) The Pfahlgraben and Saalburg in Germany, Archaeological Journal, 61:1, 319-325, DOI: 10.1080/00665983.1904.10852974

To link to this article: http://dx.doi.org/10.1080/00665983.1904.10852974

曲 Published online: 17 Jul 2014.

Submit your article to this journal $\widetilde{ }$

III Article views: 3

Q View related articles $₫$ 


\section{THE PFAHLGRABEN AND SAALBURG IN GERIIANY. ${ }^{1}$}

By JAMES HILTON, F.S.A.

The remarks which I purpose making on the subject of the Pfahlgraben and Saalburg Camp require some repetition by way of introduction. I refer to a paper I ventured to produce at a meeting of the Institute in 1884, which is printed in the Archaeological Journal, Vol. XLI, page 203. The Pfahlgraben, known also by the appellation, "Limes Imperii Romani", was a military barrier or line of boundary made by the ancient Romans in Germany against the unconquered tribes northwards of the country occupied by the Romans themselves. It was but a mound or bank of rough earth and stones mostly taken out of the adjoining ditch, without a continuous stone wall to retain it. It extended in a very irregular course from the vicinity of Ratisbon on the River Danube, to the Rhine a little below Coblenz, its whole course being 344 English miles according to the German authority, while a direct course would be about half that length. A similar defence was built of stone also by the Romans across Britain, as is well known, extending from Newcastle to Carlisle. In each case permanent fortified camps were constructed with lesser stations for the soldiers on guard, at intervals between them.

Our attention is now drawn to one camp of the Pfahlgraben, and that a very important one, on the Taunus range of hills near Homburg, v. d. Hohe, called the Saalburg. Up to the middle of the nineteenth century this spot, in extent nearly eight acres, in shape a rectangular oblong, was enclosed by a double walled vallum and fosse; during the lapse of centuries this became bare and ruinous, and the stone of its buildings became a quarry for material to construct or repair

1 Read at the Meeting of the Institute, 7th December, 1904. 
buildings in Homburg and elsewhere; trees and bushes covered the surface where formerly stood the Praetorium, the governor's house, the soldiers' barracks, and the needful storehouses, while dense forest occupied the neighbouring hills. In the year 1883, when on a visit to Homburg, I made several excursions to the camp ; it had then been cleared of these natural obstructions, and some excavations conducted about 1853 by a German antiquarian society had laid bare the foundations of the camp buildings, after the manner which has been accomplished at Silchester (in our own land), without any attempt at reconstruction, except at one angle of the enclosure, where a well-judged repair of a bit of the wall rampart and fosse had been effected, to make clear some of the Roman methods of defence which had existed all the way round. The ruins of the four entrance gateways were not meddled with. The condition of the spot is well represented in the illustrations of a careful and learned essay by Dr. Thomas Hodgkin, in 1882, printed in Vol. IX, pp. 73-161 of the Archcieologia Aetiara of the Society of Antiquaries of Newcastle-on-Tyne.

Now, in the beginning of this twentieth century, the respect which is usually shown for genuine ancient works of interest by thoughtful and single-minded archaeologists in Britain, and in many other distant foreign lands, is disregarded at the Saalburg, where all has been absolutely restored, rebuilt, and reconstructed according to what is thought to have been its appearance at the period of the Roman occupation. Elaborate buildings appear in the place of foundations almost level with the surface which were laid bare by the clearing away of the earth which had buried them for past ages. A new big building occupies the position of the Praetorium, which is destined to hold the contents of the excellent Roman Museum at Homburg; other buildings have been set up for modern occupation, and one may expect as a natural sequence that a tavern may be brought into existence in place of a supposed Roman canteen. The two gateways north and south, called the Porta Decumana, and the Porta Praetoria, also the Porta dextra and the Porta sinistra, have been entirely rebuilt, with square sloping roofed towers or guard rooms in supposed 
imitation of the original Roman structures, and the entire rampart of the camp is restored and crenellated.

My travelling days are over, and I have been unable to renew my visits to the Saalburg. I have however procured, and now exhibit a set of picture post-cards recently published, eighteen in number, which cheaply though accurately depict the present aspects of the camp; original photographs are not accessible, but the photograph process is evident in the post-cards. A new statue of the Roman Emperor Antoninus Pius presides at the Decuman gateway between the two openings, another new statue of a Roman soldier stands at the roadway leading to the Uecuman, as if a sentry on guard: and at a building in the camp stands a statue representing the "Genius of the Post"-the pedestal is utilised as a letter-box; and a post-office has already sprung up to serve the place which as yet is without a population to use it. This last-mentioned statue is made after an original statuette preserved in the museum.

Four other pictures, evidently reproduced photographs, represent the arrival and presence of the Emperor William II. at the Saalburg. It is well known that all this modern work owes its existence to the auspices of the Emperor, and was carried into effect under instructions which could not be opposed. It is stated that the late Emperor William I. frequently visited the Saalburg, taking great interest in the camp and schemes for its future condition. The distinguished names of the late Colonel A. von Cohausen, "Conservator," and of $\mathrm{L}$. Jacobi, "Architect," are associated with the modern works now completed under the superintendence of the last named; the earlier iuvestigations were conducted by them jointly. A modern German work commenced by the late Cohausen, and completed by Jacobi, was published in 1897, Romerkastell Saalburg bei Homburg. Vol. I contains many woodcuts showing the condition of the place before the reconstructions. Vol. II consists entirely of plates, most representing objects found when excavating at the ruins previously thereto.

Much has been written by other German antiquaries upon the whole subject; also by English investigators who have traversed the Pfahlgraben in its length or in 
its parts. In this connection may be mentioned James Yates, whose narrative with map and illustrations may be read in the Proceedings of the Institute at the Newcastle Meeting, Vol. I, pp. 97-134, in 1858; the essay by Dr. Hodgkin above referred to; and the notes by Rev. Joseph Hirst in Archaeologia Aeliana, Vol. IX, p. 73. Outside the camp there are many modern constructions completed or in progress, made to represent what the Romans had built there, but of which only foundations survived to these modern times; for instance, huts or cottages for the usual population in connection with a camp, the hypocaust and the villa of the Emperor Caracalla, the early existence of which is evidenced only by the excavated substructions. And a little way off a tramway is ready to convey the antiquary from Homburg to the Saalburg, in place of four miles agreeable walk by the road along which the Roman legionaries marched until fifteen centuries ago when the Roman sway ceased.

Some Roman inscriptions engraved on stone have been exhumed at the camp (or "castellum"); and some modern onesare now to be seen, thus-over the Decuman Gateway:

Guzlelmus II Friderici III. filius Guilelmi magni nepos anno reani $X V$ in memoriam et honorem parentum castellum limitis Romani Saclaburgense restituit.

At the same gateway on the pedestal of the statue of Antoninus Pius:

Imperatori Romanorum Tito Aelio Hadriano Antonino Augusto Pio Guilelmus II Imperator Germanorum.

On the pedestal of the post-office statue, thus, in capital letters :-

\section{I . NHD . D. GENIO \\ VEREDARIORVMNN \\ ANTONIANVSREMVS}

DENKSTEIN DER VEREDARIER (POSTREITER) GEFV NDEN IM LIMESKASTELL KAPERSBVRG

Letter Slot.

CVRSVS PVBLICVS

(REICHSPOST) 
What shall we say to this treatment of archaeological remains? Opinions may differ within the limits of approval and condemnation, or between intelligence and indifference, but among the audience of archaeologists whom I have the honour to address I doubt if any one would venture to approve of what the picture-cards truthfully represent, and the way in which the Saalburg has been treated by the obliteration of all evidence of its antiquity. What, on the other hand, may be alleged by others who think differently? In justice let it be regarded as a pretty exhibition, an instructive model of a Roman military work. Without presuming to dictate in a captious spirit, it may be suggested that such a work might have been put up at some neighbouring spot where ample space exists, but in truth it stands now as an example of what should not have been done at the Saalbur. The authority tor some of the rebuildings there may have been derived from the sculptures which adorn Trajan's column at Rome, as depicted in the engravings thereof by Fabretti; but they can hardly be regarded as evidence of what really stood at the Saalburg, those sculptures were intended to represent scenes at another period and place in history, namely, the campaigns of the Romans in their Dacian wars.

soon after the reading of this paper there was published at Gotha, in Germany, by F. A. Perthes, a grand set of pictures done in chromo-lithography; the leading one is $33 \times 48$ inches in size, the others abuut half those dimensions; the laryer one shows the camp as it now appears, surrounded by forest and agreeable scenery, the others show the various new buildings exterior to the camp with men engaged in the work of reconstruction. The modern Saalburg will doubtless afford some instruction to visitors who are not influenced by the feeling of archaenlogical regret at the transformation which I have thus presumed to place on record in the Journal of the Institute. The accompanying illustrations which I give by the kind permission of Herr L. Jacobi and Messrs. Lautz and Balzar, of Darmstadt, will elucidate what I have ventured to describe. 


\section{THE ILLUSTRATIONS.}

Plate I.

Porta Decumana looking north, showing the general aspect of the camp from the principal gateway, after it was set in order and cleared from the growth of trees, etc., by the German antiquaries prior to the year 1880.-From a contemporary drawing.

\section{Plate II.}

The Praetorium at the same period showing the foundations of the ancient buildings as laid bare by excavating prior to 1880 . - From a contemporary drawing.

\section{Plate III.}

The Porta Praetoria at the opposite end of the camp as seen from the interior.-From a contemporary drawing.

These three illustrations are copied by permission, from Volume VIII of Archaeologia Aliana of the Society of Antiquaries, Newcastleon-Tyne for the year 1888 .

\section{Plate IV.}

The Porta Decumana (the principal entrance) as reconstructed; outside view.

The same showing the modern statue of the Roman Emperor Antoninus Pius and the inscription denoting the modern reconstruction.-By permission.

\section{Plate V.}

The Porta Dextra, exterior view, a facsimile of an original photograph taken by the "Kunstanstalt Lautz u. Balzar, Darmstadt."- By permission.

External view of the camp showing the crenellated wall and the position of two of the gateways; modern constructions.

\section{PLATE VI.}

The foundations of the ancient Praetorium which occupied a central position in the camp, as they appeared prior to the reconstruction.

Modern buildings on the same spot.

\section{Plate VII.}

Exterior view of a modern building in the Praetorium; the presence of the German Emperor William on 25th August, 1903, is represented.

Modern building, same occasion and date; showing also a modern statue.

\section{Plate VIII.}

Two views of modern buildings in the Praetorium, showing two of the restored ancient wells and the canopies erected over them.--By permission. 


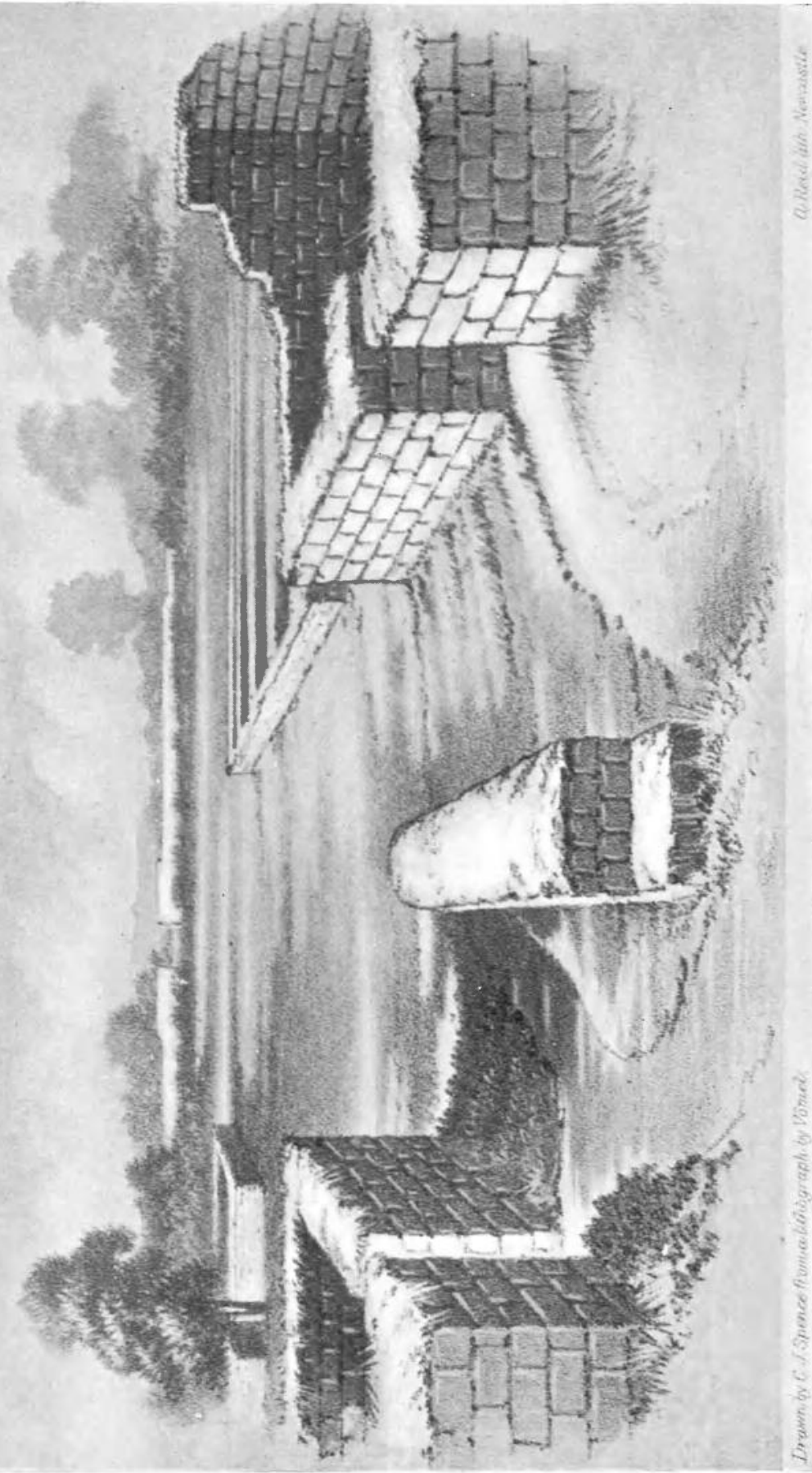




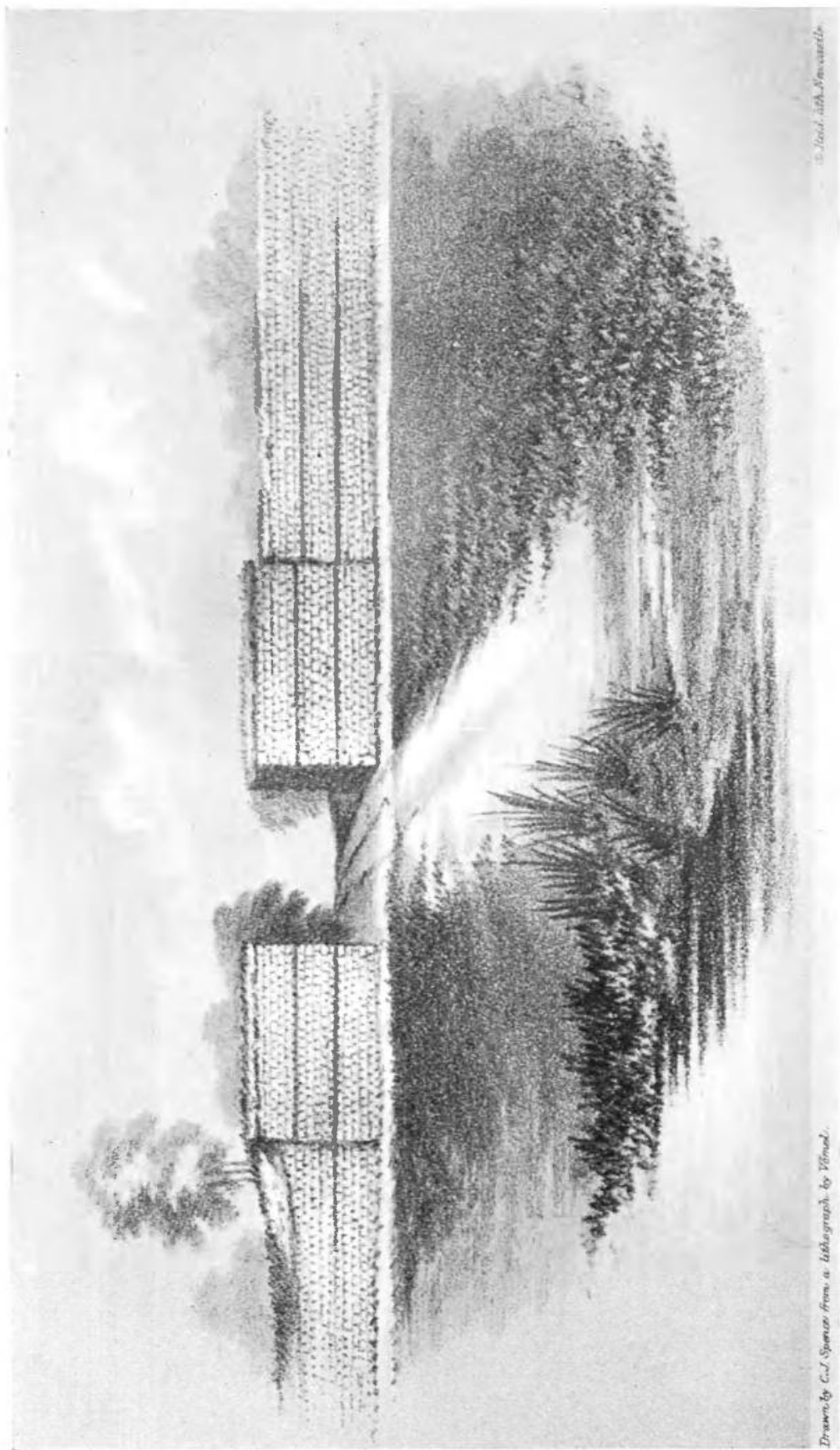



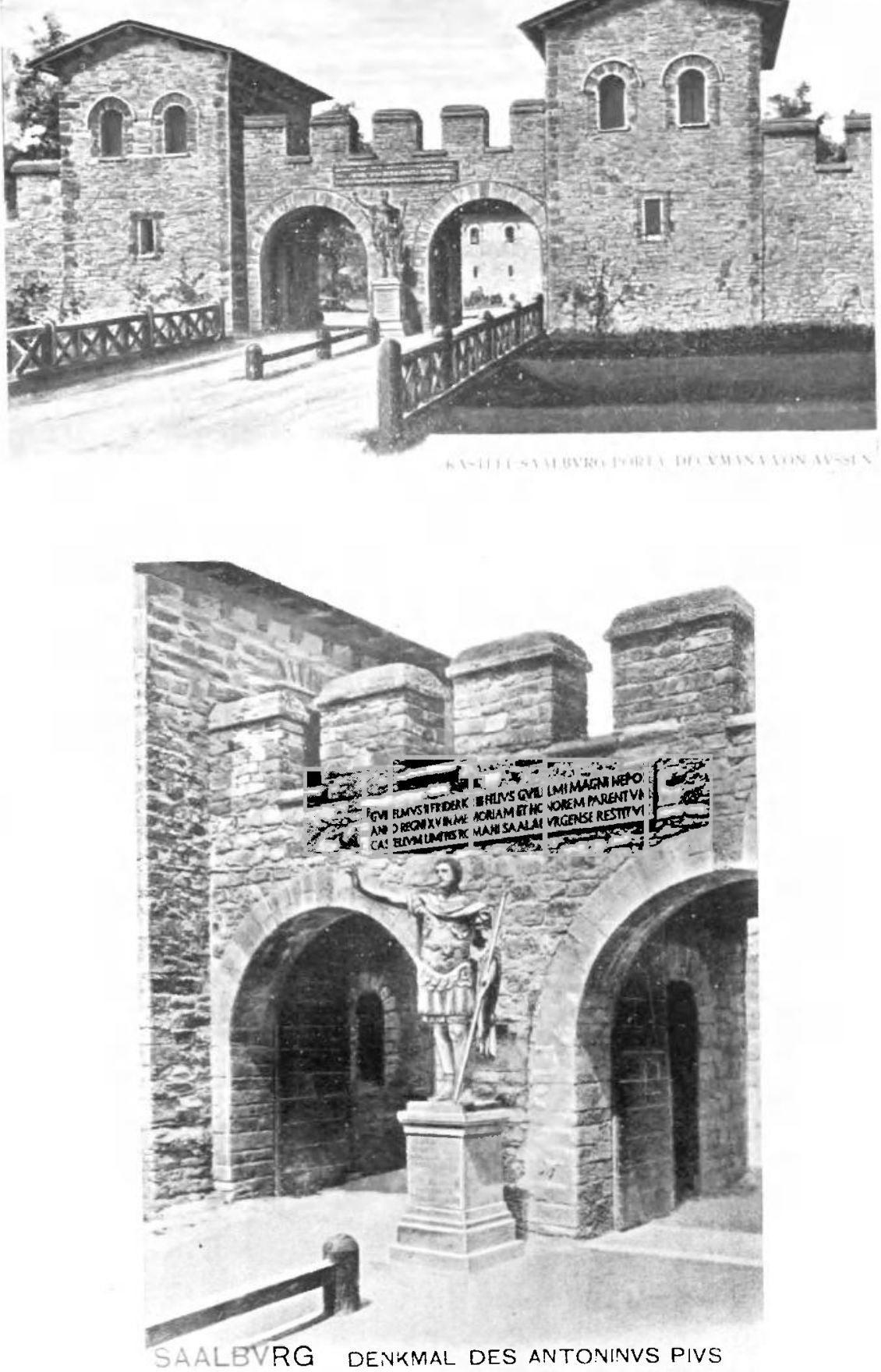

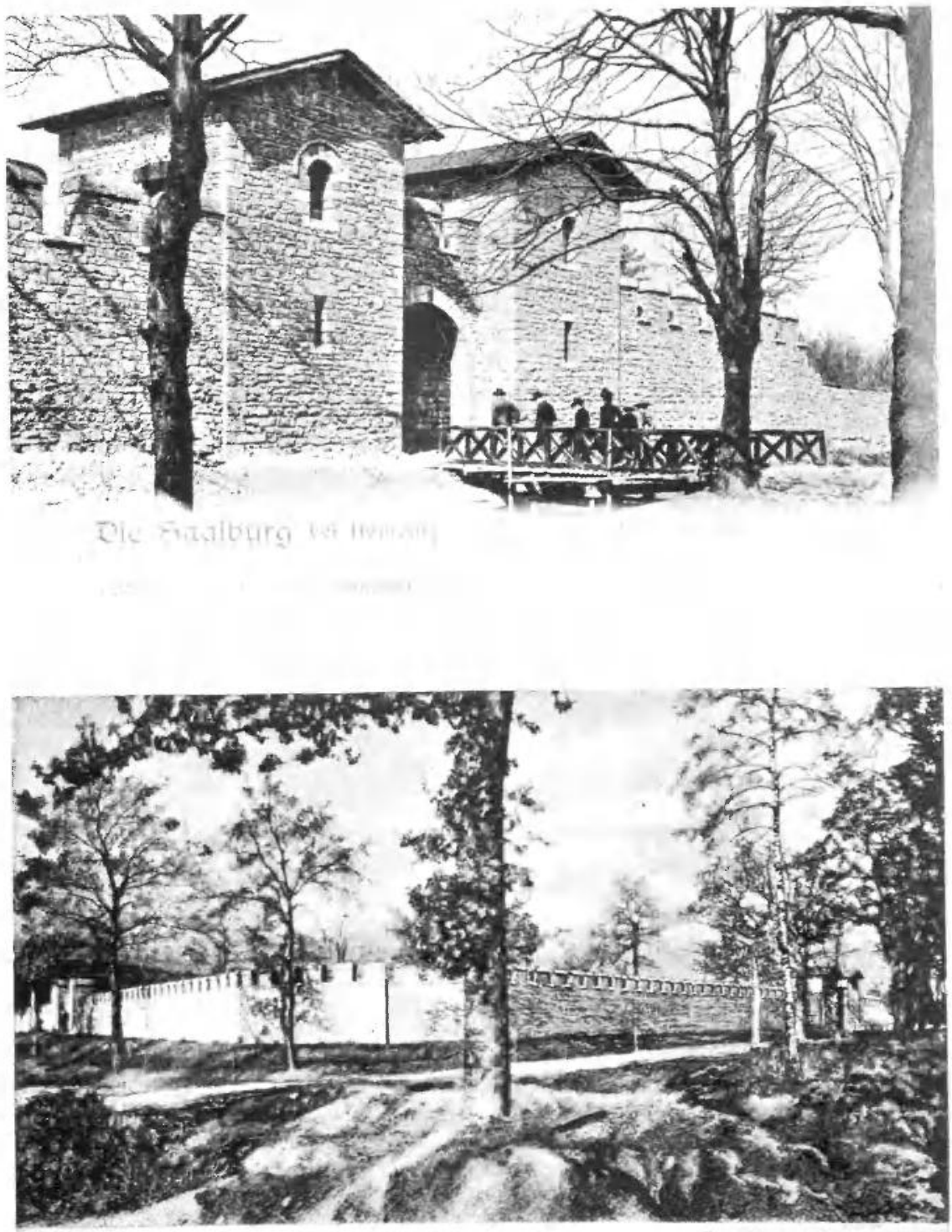

R MERCAETELL SAALBVRG BEI HOMEVFG $Y$. D. WÖHE 


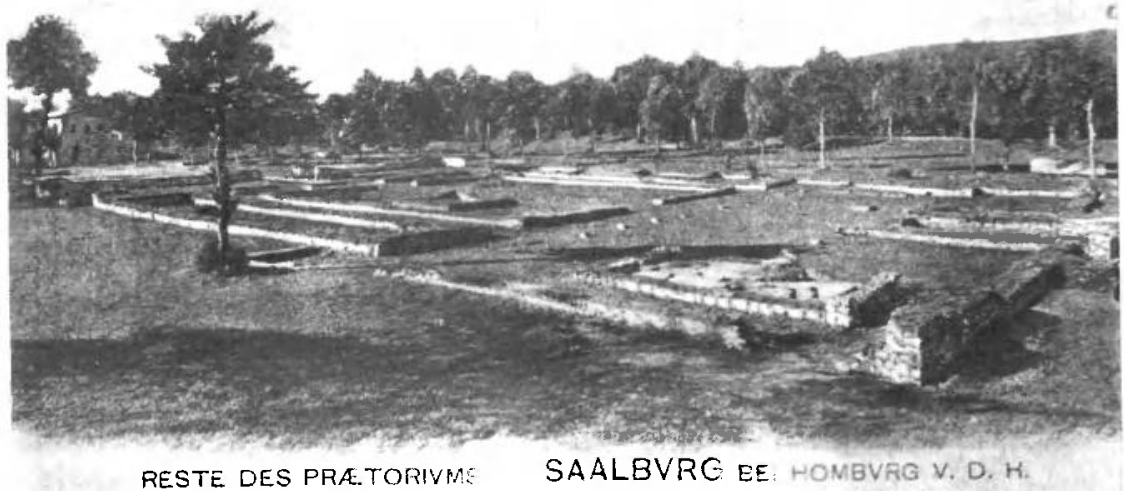

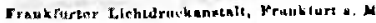

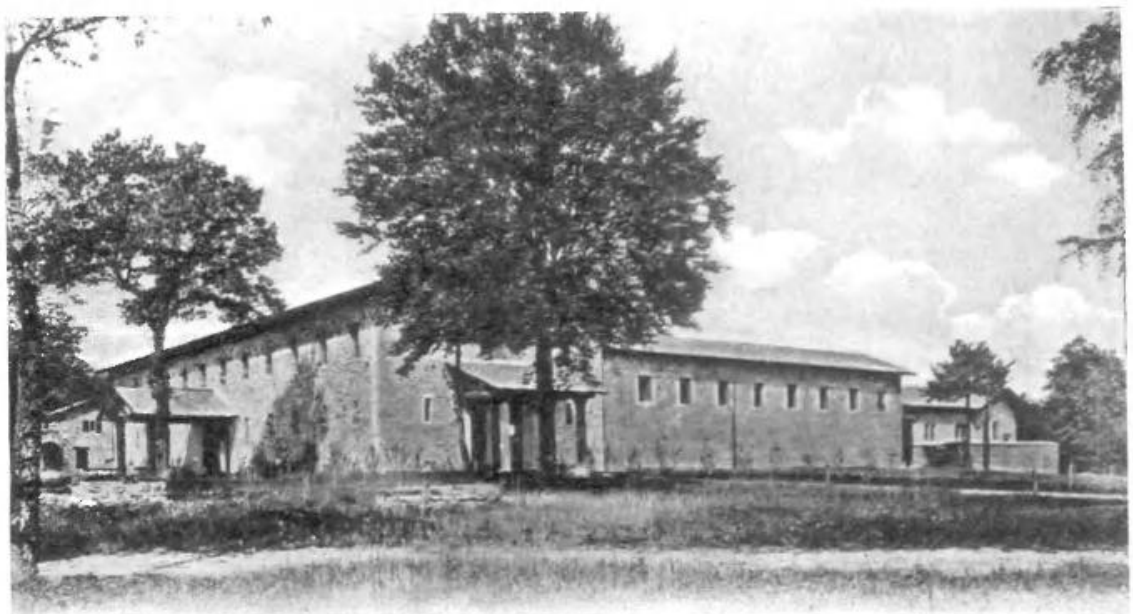




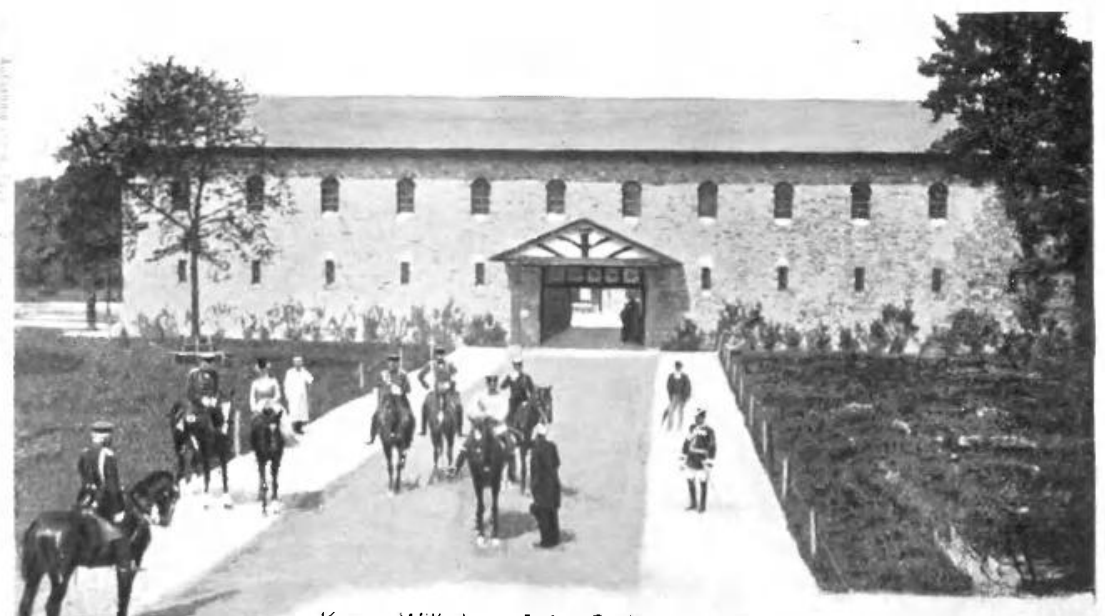

Kasser Wilhelm zul der Saalburg am 25. Aug. 1903

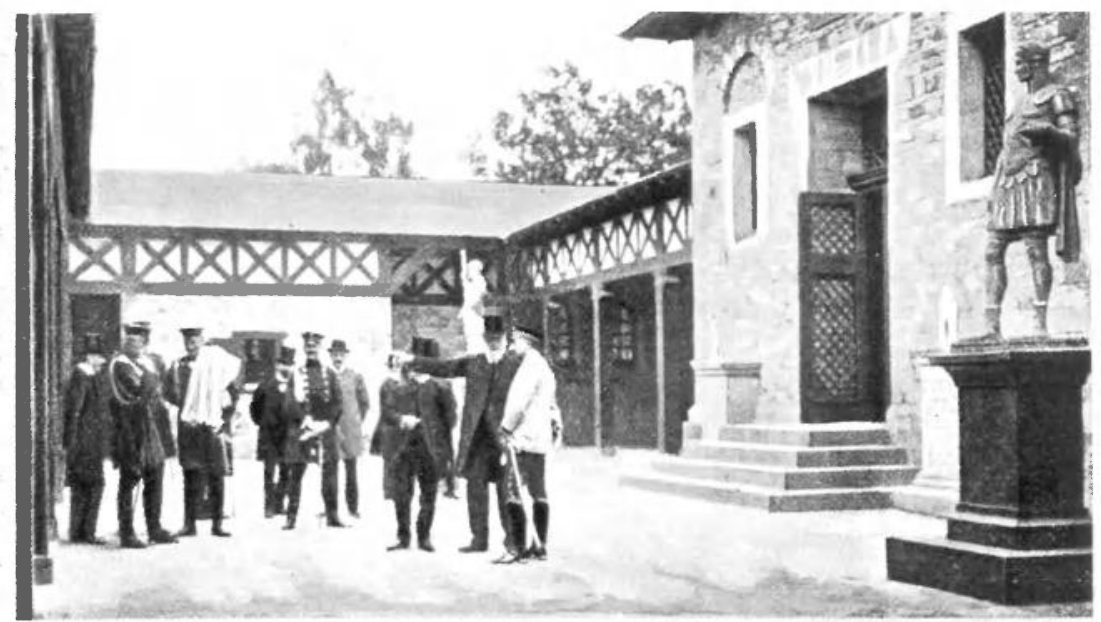

Kastell Saalburg.

Withelm in Peristyt am 25. Aug, 1903. 


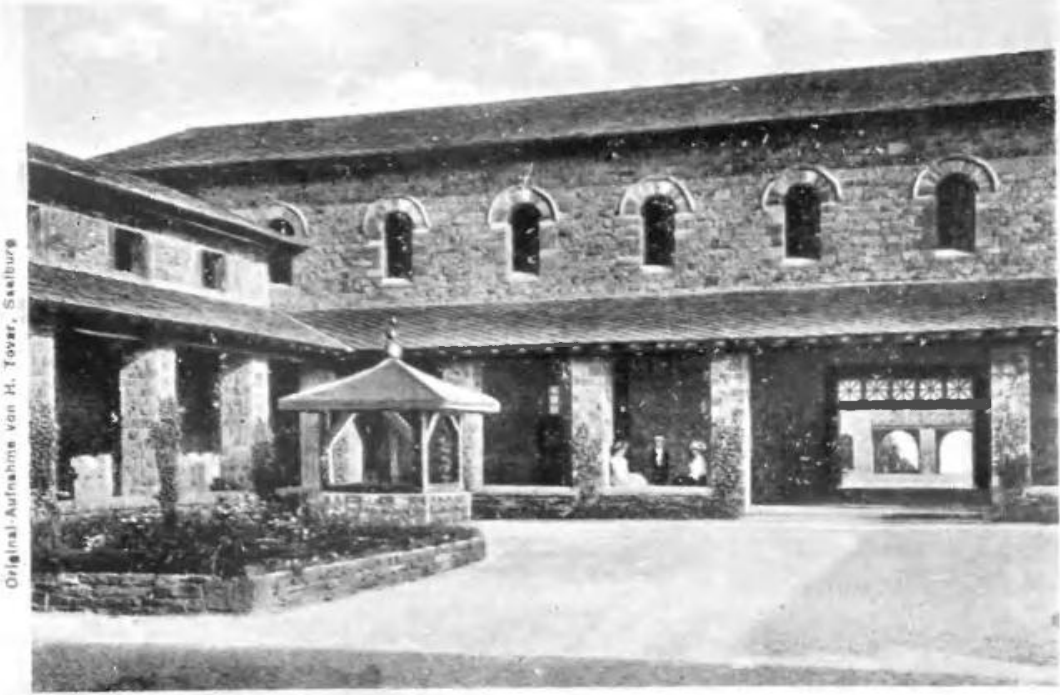
SAALBVRG BLICK IN DAS ATRIVM DES PRAETORIVMS

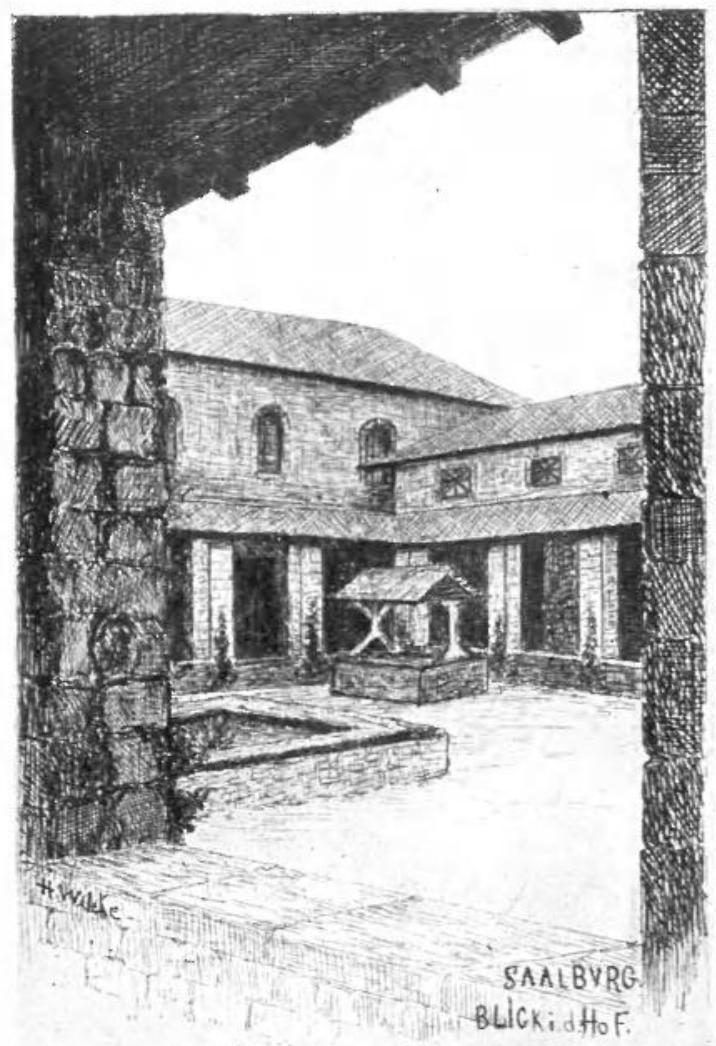




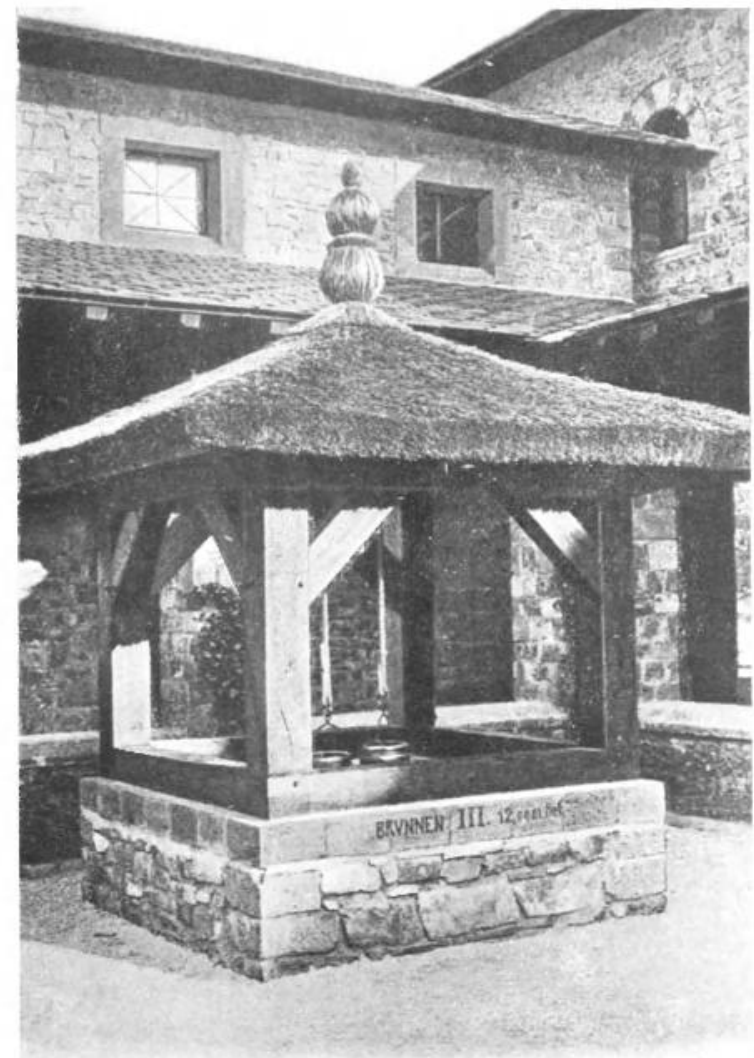

KASTELL SAALBTRG. BRVIAEX III IM ATRIVM. 
SAALBCRG.

PLATE $X$.

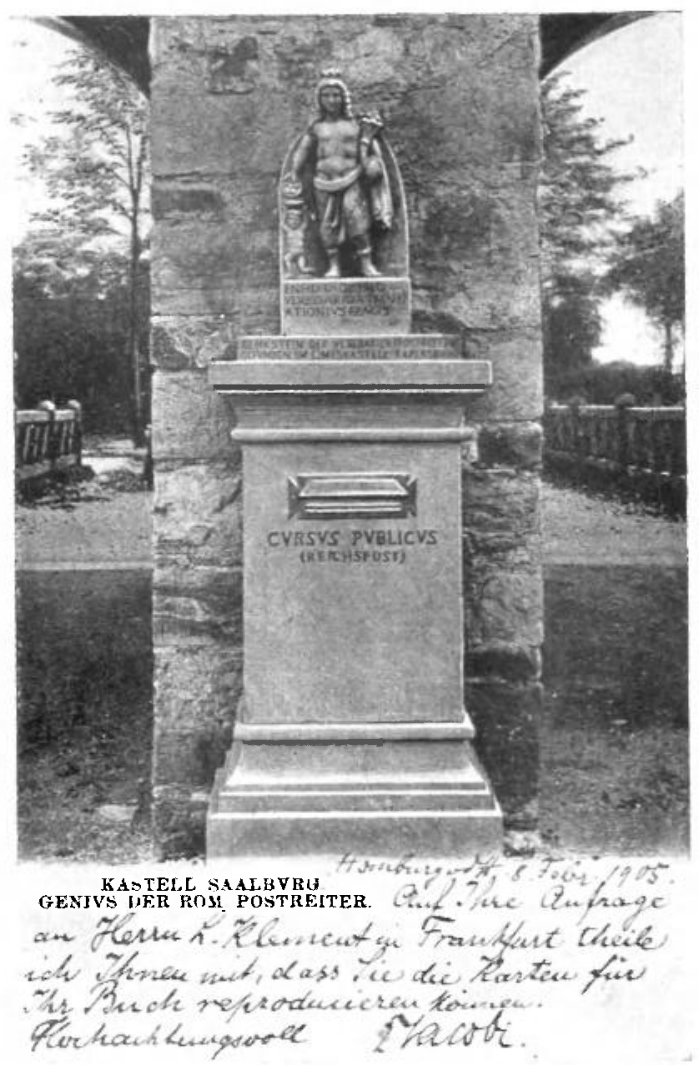



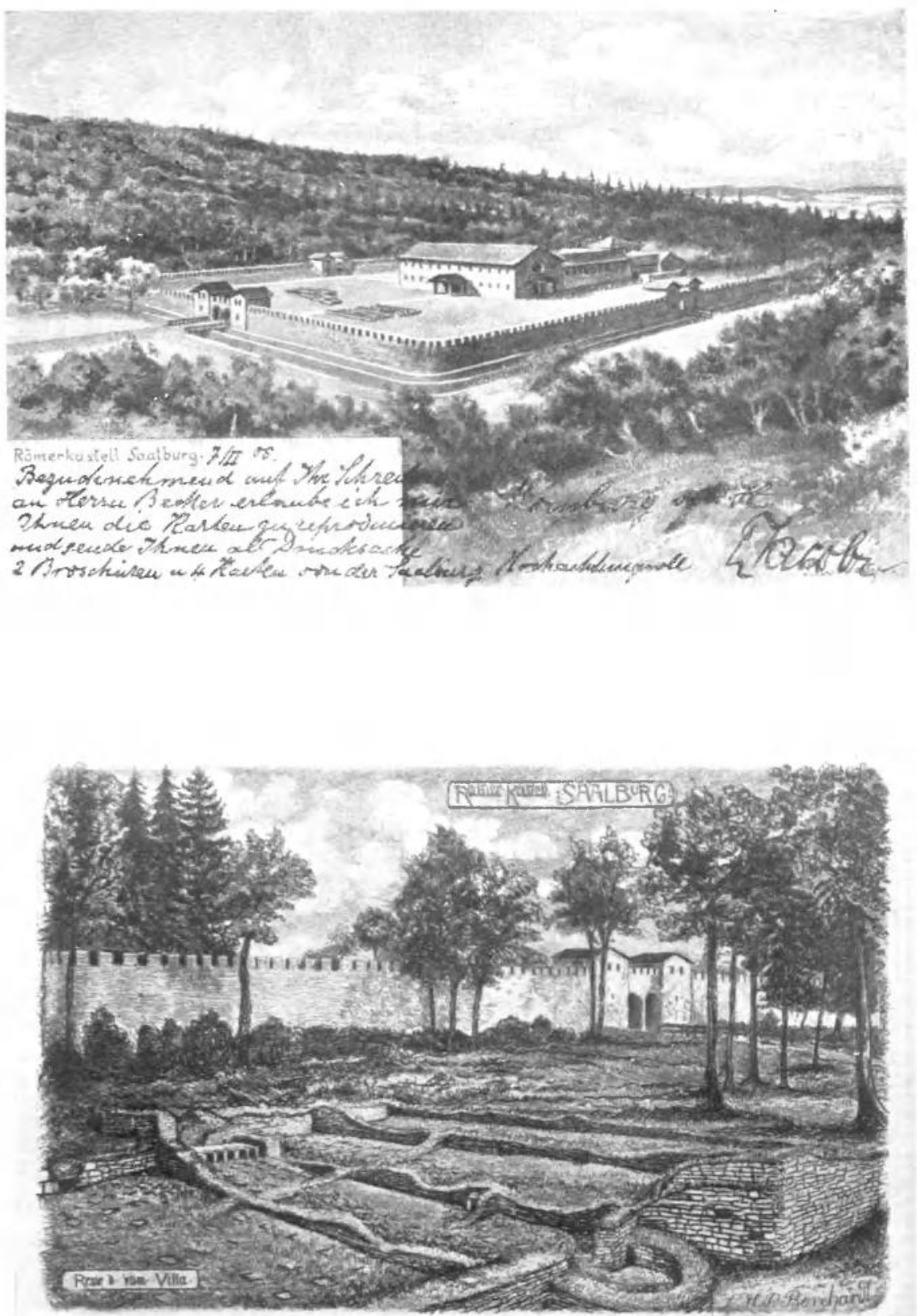
THE PFAHLGRABEN AND SAALBURG IN GERMANY. 325

\section{Plate IX.}

An enlarged view of one of the wells shown on Plate VIII.

\section{Plate X.}

The statue copied from a Roman statuette in the museum, made to represent the "Genius of the Post"; the pedestal contains the letter box.

\section{Plate XI.}

General view of the present appearance of the Saalburg : by permission of L. Jacobi.

General view copied from an original photograph (by permission) of the ancient foundations of the Villa of Caracalla outside the Porta Decumana. 